\title{
The Disciplinary Power of Museums
}

\author{
Ka Tat Nixon Chen
}

\begin{abstract}
Museums are powerful. Museums can discipline the mindset of people. Owing to the fact that people in general consider museums are reliable sources for gaining knowledge and understanding their surrounding, this facilitates museums to exercise their disciplinary power. This paper is to look into the ways how museums discipline the mindset of people. The research methodology used for this study is purely qualitative. The validity of this paper lays in those primary data collected through personal communication with administrators of museums, and is supported by secondary data from books. The findings are that museums can discipline the mindset of people to make them believe in a hierarchy of social and world order, to scope their understanding of their relationship with the world and to instruct and to edify them. Based on a situation that people in general consider museums are reliable sources, this paper raises the concern of the neutrality of museums as disseminators of knowledge and facilitators of making people understand themselves and their relationship with their surrounding at large.
\end{abstract}

Index Terms-Museum, discipline, to create a social and world order, to instruct and to edify, to understand the world.

\section{INTRODUCTION}

In his book written in 1975, Surveiller et punir: Naissance de la Prison (Discipline and Punish: The Birth of the Prison), Michael Foucault (1926-1984) raised his concern of the disciplinary power of different types of institutes such as hospitals and schools. Foucault saw the possibility of these institutes to form a vast network to regulate the behavior of people in a society [1]. Museums are a part of these institutes. Museums have the power to discipline the mindset of people by directing people to see what they should see and to know what they should know inside museums. Through these, museums can regulate the thinking of people to make sense of and to understand themselves, the world and their relationship with the world.

Museums have long been compared with universities and libraries for their educational role. The origin of museums was to provide education. It is widely believed that the emanation of the museum concept was related to the Muses whose residence laid the foundation of museums as a place for education [2]. However, it was in the beginning of the $20^{\text {th }}$ century that some re-emphasized the educational role of museums. In 1917, John Cotton Dana, the director of the Newark Museum, in his writing "The Gloom of Museum" emphasized the importance of museums to perform their teaching role. He wrote: "to make itself alive, a museum must do two things: It must teach and it must advertise (cited in

Manuscript received April 3, 2013; revised June 3, 2013.

$\mathrm{Ka}$ Tat Nixon Chen is with Tourism and Hospitality Division, Mahidol University International College, Thailand (e-mail: nixon.che@mahidol.ac.th).
Anderson, 2004, p. 25) [3].” Dana suggested museums to ally with educational and art institutions. In 1942, Theodore Low, a museum educator of the Metropolitan Museum of Art, in his seminal piece "What is the Museum?" insisted that museums have to be another education resource along with schools and universities [3]. In 1974, International Council of Museums (ICOM) defined a museum as "a non-profit making, permanent institution in the service of society and of its development, and open to the public for purposes of study, education and enjoyment, material evidence of man and his environment [4]." In 1992, the landmark report of the American Association of Museums (AMM), Excellence and Equity, confirmed education was the core role of museums [5]. In the late 1990s, Alan Howarth, the former Arts Minister of Britain, asked museums to use advanced digital technologies to rediscover their educational purposes [6].

As a place to provide education, museums are normally considered a reliable source for people to get information and knowledge and to understand their surroundings. In the United States of America, many regarded museums as the most trustworthy and objective institutions for children education [7]. According to a survey done by the American Association of Museums (AAM), 87 percent of the respondents judged museums trustworthy while 67 percent and 50 percent respectively judged books and television news trustworthy [7].

Seeing the reliability of museums, schools, in particular primary schools often partner with museums and arrange museum tours for their pupils. In Dearborn, USA, a high school partnered with the Henry Ford Museum and Greenfield Village and used them as its laboratory to facilitate teaching of teachers and learning of students [3]. In Bangkok, some schools associated with the Museum of Siam and organized education tours to the museum. This resulted in more than $75 \%$ of visitors of the museum being students, in particular pupils (Alisa Bhoocha-oom, Museum Enterprise Manager of the Siam Museum, personal communication, April 4, 2012). "We need to educate kids...innovations and maybe stem the brain drain," said Klotz King, manager of the Tomorrow's Indiana Gallery [8]." In London, to celebrate its $250^{\text {th }}$ anniversary, the British Museum, in collaboration with Samsung, used technology to enthuse young people. Samsung provided the museum with wireless technology and digital devices for children to interact with the collections of the museum such as taking photos of, videoing and creating their own animation of the exhibitions of the museum [9].

Facing a situation that many believe in the trustworthiness of museums, some have reservation on the "truth" of the content of the knowledge and the information inside museums. They question about the knowledge and the information inside museums that could be manipulated by museums to introduce a discourse to influence the value or 
the sense of righteousness of people. Foucault commented discourses were "systematic conceptual frameworks that defined their own truth criteria...imply particular institutional arrangements [10]." Gurian (2006) [11] raised her concern that the "truth" of museums was synthesized in the eye of the beholder, and was therefore subject to change. As a keynote speaker at "Museums as Socially Responsible Institutions" conference in 1988, she remarked that no museum had ever been value neutral. Marstine (2006) [7] saw that museums were to create "an ideologically based narrative context that colors our understanding of what's included (p.4)."

In fact, from the beginning of their development, museums have often been used as instruments to discipline the mindset of people to believe in what they were being told and shown inside museums. This then becomes their sense of righteousness which affects the way they understand themselves, the world and their relationship with the world.

\section{Museums ARE TO CREATE A SOCIAL AND WORLD ORDER}

Museums are to demarcate a social order of the upper class and the lower class. The Florence-based Medici Family had laid the foundation of a museum concept, which was to express the interest of the upper class: the noblemen. The family was to collect, to patronize and to commission excessive luxurious arts and architectures to show off their wealth and power, in particular their domination of Florence.

During the Renaissance period, museums in the form of Cabinets of Curiosity were to display the private collections of a new group of upper class: the bourgeoisie. This upper class was keen to explore valuable objects and those "new, unknown, or unseen that needed to be integrated into the existing perception of the world [10]." Museums were a place to display and to protect these rare and precious objects which were beyond the reach of common people. To display and to protect these objects, the upper class then had to look for or to build spacious and expensive residences which were in the form of temples, castles and palaces. Museums became an exclusive interest and symbol of the upper class.

In the late Renaissance period, following the collecting practice of the upper class, common people started to collect objects. As object collecting became "a mark of status...for identifying and expressing social distinction [10]," common people started to follow the practice. However, different from the upper class which collected valuable objects; common people were keen on collecting specific objects such as tulip bulbs and ancient medals caps. People were to be judged for their good tastes, education and social status through those objects collected [10].

The emergence of the Age of Enlightenment was a response to a disordered world that was marked by the decline of patrimonial power, the rising bourgeoisie and the rapidity of modernization. The world was thought to be distorted by industrial and political revolutions that had disrupted the traditional mode of power and control [10]. The western monarchies started to make use of museums to retrieve a social order with the monarchies at the top of the order. Gradually, they extended this social order into a world order which were to be headed by the western monarchies.
Museums were to illustrate the achievements of these monarchies who thought they had successfully brought an equal opportunity for all people to progress. Museums were then displayed with valuable objects which were originated from those countries being enlightened. They were to demonstrate a social order of the conquerors and the conquered and to prove the success of these conquerors in bringing progress to those countries with lesser civilizations. Museums became princely galleries to represent the power and achievement of monarchies and nobles.

Today, some museums are still keen on collecting objects. They are to continue the object collecting role of museums of the $17^{\text {th }}$ century. However, instead of collecting valuables or things to show connoisseurship, some museums focus on collecting specific things. The National Toothpick Museum collects and displays toothpicks. The museum illustrates to visitors the use of toothpicks could avoid tooth decay and gum disease. The Museum also display toothpicks used by famous politicians and events which were associated with great historic events such as those which were chewed by Roosevelt, Churchill and Stalin at Yalta [12]. While the National Toothpick Museum collects and displays toothpicks, some museums collect and display objects such as airline sick-bags, lawnmowers, pencils, packaging and toilet covers.

Some see their mission is to protect those masterpieces which are evidences, glory and pride of their countries' inheritance. One example is the Elgine Marbles which were originally from the Parthenon in Greece. Despite many people suggested that Greece was the legitimate owner of the Marbles and that the museum should return the Marbles to Greece, defenders who supported the Marbles to remain in the British Museum claimed that the Marbles were better cared for in the Museum. They claimed that it was quite unlikely that the Greek government could look after the Marbles owing to the fact that the Parthenon is a "ruin that can never now be restored [13]." Therefore, today's museums are still regarded by many people as princely galleries. People often relate museums to images of kings and queens and armour and weapons.

\section{Museums are to Let People Understand Their RELATIONSHIP WITH THE WORLD}

During the early Renaissance period, museums under the name Wunderkammer (wonder-room) in northern Europe or studiolo in Italy were to represent a world from the perspective of mankind. These museums were for the sake of the interests of those elites well-represented by wealthy merchants, artists, physicians and scholar to collect rare and eerie objects such as mineral specimens, antique statuaries, ethnographic materials and distorting mirrors. They act as a miniature world to "mediate the microcosm of humankind and macrocosm of God and the universe [7]." Despite these museums act as playhouses for these groups of people, they were to introduce to humankind a secular world amid the fading influences of religion.

At the Age of Enlightenment, the western monarchies bore a mission to enlighten those with a lesser civilization. This mission of enlightenment influenced the mindset of people to such an extent that they used their civilization standard to 
judge that of other countries. In a chapter of a book which was compiled by George Bacon in 1893, the author recorded his meeting with King Pinklao, the Uparaja (the second king) of Siam in the late $19^{\text {th }}$ century. In the chapter, he wrote that he was especially pleased with the "civilized" hospitality that he received from King Pinklao. He was served with some "civilized" cakes and some "civilized" tea and coffee. To him, the cakes and the beverages were "good index of civilization [14]."

The Louvre in Paris was once a museum to make the French believe that they were the most superior race in the world. In 1803, the Louvre was renamed Musée Napoleon. The exhibits of the Louvre and the content of the catalogues and guidebooks of the Louvre were designed by curators of the Louvre to make the French believe that they were the most civilised and best race in the world.

After all, the setting up of museums in some non-occidental countries such as Siam and the Ottoman Empire was to promote a Western ideology or to adapt this ideology to their political, social and cultural context to free them from Western intervention or integration.

Today, some museums still consider their main role is to guide people to see themselves, their societies and their relationship with the societies and the world at large. Museums, in particular national museums, try to idealize the mindset of people of their countries. Some use the tactics of making certain objects or certain period of time particularly significant and representative. Some use the tactics of evading certain facts or details. Some use the tactics of dominating the mindset of people with certain images or concepts. In the 1940s, the Nazi Party stockpiled Jewish materials to set up a museum with an attempt to eradicate the Jews [10]. In 1970s, after the Iran Revolution, the Tehran Museum of Contemporary Art banned the display of modern Western art to protect Islamic values.

The British Museum is an extension of the idea of Enlightenment, the concept of Britishness, (Justin Morris, Head of Strategic Planning and Collections Services of the British Museum, personal interview, March 13, 2008). Neil MacGregor, the Director of the British Museum, in his introduction of the museum said: "We maintain a collection of things from the whole world that will be freely accessible to the people of the whole world. We try to interpret those principles for each new generation, but however much the details change, we remain true to the basic Enlightenment ideals [15]." According to Justin Morris, the museum was to let people understand their world from two scales. At a micro scale, the British Museum was to reflect to the world and the British that Britain was a multi-race society; to be British was to be multi-cultural. At a macro perspective, the museum was to made visitors aware of and understand their own cultural identities and their relations with the world.

\section{Museums ARe to Edify ANd to Instruct People}

The continuous search for the old or exception in the beginning of the Renaissance Period had grown to such an extent that the world became too complex and complicated to be represented by the Wunderkammer and studiolo. Religion was no longer considered to be able to advance human progress. Rationalism and science had begun to dominate the mindset of people. The Wunderkammer and studiolo gradually evolved into spaces of rationality. Different from these "museums" which were stuffed with objects, people started to look into systematic ways of collecting and organizing objects into meaningful collections. Museums started to rationalize their practice of collecting. Objects were categorized along taxonomic lines "to map the world patterns [10]." Objects were collected in accordance with their significance and meaning, and to be categorized in accordance with their chronology and territory. Those which did not fit into these criteria was either rejected or made to fit. Museums became space of specialization such as natural history museums, science museum, ethnology museum and anthropology museum [10].

After that, museums attempted to rationalize the thinking of people. Art had become a science and a visual education. Art was categorized and to be appreciated in accordance with their period, their civilization and their nationality [10]. The size and measurement of paintings were standardized. Those sizes that did not meet the standard had to be cut or extended. Classical sculptures had to be in perfect shapes. Those with missing limbs had to have their limbs restored. Different schools of thought started to develop to rationalize people's understanding and appreciation of arts. The significance and the appreciation of artistic products were rationalized by the introduction of art history or art critics.

Today, this way of art rationalization still governs the mindset of art appreciators. "Now not only are you a looker of art, but you must be a looker of art either from the Lacanian camp, the Baudrillardian camp, the Derridian camp...,who knows, even the Pavlovians. But it's almost creating a hermetic language of priesthood (Patrick Muphy, the director of the Philadelphia's Institute of Contemporary Art, [16]." Some avant-garde artists looked into museums as places that prohibit creativity. They accused museums of cutting creativity and animating museum literature [10].

The Hiroshima Peace Museum and the Nagasaki Atomic Bomb Museum speak critically of the use of atomic weapons and to honor the death of those victims who were killed by atomic bombs during the Second World War. The museums are to spread the message of peace. However, hidden under the rationalization of peace are the advocate of the Greater East Asian Co-prosperity Sphere by Japan, the control of those conquered countries by Japan and the forcing of female into sex slavery by the Japanese armies during the Second World War [10].

\section{CONCLUSION}

Museums are to exercise their disciplinary power. Started as a place to demonstrate their political, economical and social status, the Medici family laid the foundation of museums to demarcate a social order between the ruling class and those to be ruled at a regional scale. This concept of demarcation finally evolved to an international scale that the western monarchies in the Age of Enlightenment began to make use of museums to illustrate a world order between the conqueror and the conquered.

During the early Renaissance period, "museums" were to 
let people see a new world from the perspective of mankind. These "museums" reflected the social anxiety to liberate from the shackle of theology and to explore a new world of its own accord. They were to introduce a world which was headed by human being: the cosmology of mankind.

The continuous search for the odd or exception had grown to such an extent that the world became too complex and complicated to be represented by the cabinets. Secularism had evolved into a stage that rationalism began to govern the mindset of people. People searched for rationality and science. The search for rationale had grown to such an extent that the mission to mould a homogeneous society started to sprout in the mindset of the monarchies in Europe. The "museums" at the early Renaissance period gradually evolved into spaces of specialization and rationalization. Art had become a science and a visual education. The duty of art was to instruct and to edify the public.

Museums, finally, became public spaces to illustrate the achievements of those nations who thought they had successfully brought to all people an equal opportunity to progress. Museums displayed valuable objects originated from those countries that were being "enlightened". Museums were to demonstrate a social and world order which was headed by the western monarchies. Museums were to enlighten people and to prove the superiority of the western civilization.

The world experienced dramatic changes in the $20^{\text {th }}$ century. In the first half of the century, the monarchies in Europe and Asia started to fall one after another: some became constitutional monarchies, while others became republics. Russia and Japan shifted the balance of power from Europe to Asia. Communism began to influence the thinking and beliefs of people. In the second half of the century, under the influence of the declaration of four basic consumer rights by J.F. Kennedy, the former president of the USA, together with publications such as the Silent Spring by Rachael Carson in 1962 and Unsafe at Any Speed by Ralph Nader in 1965, the popularity of television, the Cold War and the concern of the Vietnamese War, people became more aware of their rights, their livelihood, their environment and their relationships. Many started to criticize museums being merely storage places to preserve the physical value of objects. People began to stress the importance of museums to be relevant to society and involve communities' participations.

Museums organizations, scholars and researchers tended to appropriate the role of museum. Eventually, they saw the common importance of museums was to disseminate knowledge. Museum scholars and administrators introduced theories and models to tell museums the best way to disseminate knowledge and to facilitate learning inside museums. Museums then performed the original educational role of the House of the Muses. Museums became a reliable source for people to understand themselves. However, many museums still exercise their disciplinary power to continue conveying a discourse from the perspective of museums. People are being shown and told what museums want them see and know.

"No single museum can respond to all social needs with equal effectiveness; for this reason alone we must have a variety of museums and museum styles, serving different purposes or tackling challenges from different approaches
[17]," therefore, there are different types of museums to discipline the mindset of people in different ways. It is quite clear that the discourses of museums are not neutral. The discourses of museums are designed to convey to visitors a moment of truth in accordance with the accord of museums. After all, "museums are not neutral spaces that speak with one institutional, authoritative voice. Museums are about individuals making subjective choices [7]."

\section{REFERENCES}

[1] C. K. Sanjoy and G. Neelankantan. (2008). A Foucauldian Reading of Paul Auster's Travels in the Scriptorium in HighBeam Research. [Online]. http://www.highbeam.com/doc/1G1-274115308.html

[2] Hong Kong Art: Open dialogue, Hong Kong: Hong Kong Museum of Art, 2008.

[3] G. Anderson, Reinventing the Museum: Historical Contemporary perspectives on the Paradigm Shift, Oxford: AltaMira Press, Ed., 2004.

[4] H. S. Hein, The Museum in Transition, Washington: Smithsonian Books, 2000.

[5] L. Roberts, From Knowledge to Narrative: Educators and the Changing Museum, London: Smithsonian Institution, 1997.

[6] M2 Presswire. (1999). UK Government: Arts Minister Announces Million Pound to Boost for New Technology and Education in Museums. [Online]. Available: http://www.highbeam.com/doc/1G1-55244469.html

[7] J. Marstine, New Museum Theory and Practice: An introduction, Carlton: Blackwell Publishing, Ed., 2006.

[8] C. Banguis. (2002). Museum Showcases Technology Successes in Highbeam.

http://www.highbeam.com/doc/1P3-259804391.html

[9] D. Greek, (2009). Museums Revamp Technology in Highbeam Research. [Online]. Available: http://www.highbeam.com/doc/1G1-195947843.html

[10] S. MacDonald, A Companion to Museum Studies, Oxford: Blackwell, Ed., 2011.

[11] E. Gurian, Civilizing the Museum: The Collected Writings of Elaine Heumann Gurian, London: Routledge, 2006.

[12] S. E. Weil, Rethinking the Museum and Other Meditations, Washington: Smithsonian Books, 1990.

[13] C. Hastings. (2005). Revealed How Rowdy Schoolboys Knocked a leg off One of the El Marbles. [Online]. Available: http://www.telegraph.co.uk/news/uknews/1490023/

[14] G. B. Bacon, Siam: The Land of the White Elephant as it was and is, Williams, F. W. (Revised), (originally published in 1893), Bangkok: Orchid Press, Ed., 2000.

[15] R. Smith, The Museum: Behind the Scenes at the British Museum, London: BBC Books, 2007.

[16] C. Dubin, Displays of Power: Controversy in the American Museum from the Engola Gay to Sensation, London: New York University, 1999.

[17] I. Karp, C. M. Kreamer, and S. D. Lavine, Museums and Communities, The Politics of Public Culture, Washington and London: Smithsonian Institution Press, Eds., 1992.

Ka Tat Nixon Chen is a lecturer of the Divi sion of Tourism and Hospitality, Mahidol University International College (Thailand). He received his Ph.D. in Architectural Heritage Management and Tourism from the Silpakorn University (Thailand). His research interests are museum studies, cultural studies and cultural heritage. He is very active in writing and presenting academic papers and researches that are in particular related to museum studies. One of his recent finished researches was to look into the extent digital on-site interpretations affected learning of visitors inside museums. Dr. Chen is also very active in giving training and special lectures on tourism. In 2012, he gave four special lectures on Cultural Tourism and Interpretation and Marketing Tourism to a group of delegates from eight African countries. The special lectures were co-organized by Thailand International Development Cooperation Agency, Ministry of Foreign Affairs and Mahidol University International College. In 2013, he was invited by the Department of Tourism (Thailand) to conduct a workshop on Promoting Responsible Tourism for the Greater Mekong Sub-region Countries. 